Vol.1, No.1, Desember 2017

E-mail: jpsp@unpad.ac.id

\title{
PERBEDAAN SIKAP IBU HAMIL TERHADAP DOKTER KANDUNGAN PRIA DAN WANITA
}

\author{
Nago Tejena, Nindya Putri Aprodita, Keumala Nuranti, Aulia Iskandarsyah \\ Fakultas Psikologi, Universitas Padjadjaran \\ nagotejena@gmail.com
}

\begin{abstract}
ABSTRAK
Indonesia merupakan negara dengan jumlah penduduk terbesar keempat di dunia dengan penduduk yang mayoritas beragama Islam. Wanita muslim memegang nilai-nilai untuk membatasi interaksi fisik dengan lawan jenis, sehingga diasumsikan akan timbul kesulitan ketika bertemu dengan dokter kandungan pria. Penelitian ini bermaksud untuk mendapatkan gambaran perbedaan sikap ibu hamil terhadap dokter kandungan pria dan wanita. Partisipan penelitian ini adalah 132 ibu hamil beragama Islam yang mengenakan hijab, yang berada dalam masa kehamilan pertama. Metode penelitian yang digunakan adalah metode komparatif dan pengambilan sampel menggunakan teknik purposive sampling. Sikap ibu hamil diukur melalui kuesioner yang dibuat berdasarkan teori Sikap (Ajzen, 2005). Selain itu, melalui kueisioner serupa juga dijaring data mengenai belief of competence. Reliabilitas alat ukur sikap berada dalam kategori tinggi $(r=0.889$ untuk dokter pria dan $r=0.831$ untuk dokter wanita), sedangkan reliabilitas alat ukur belief of competence berada pada kategori sangat tinggi $(r=0.95$ untuk dokter pria dan wanita). Analisis data menggunakan teknik analisa kuantitatif dengan menggunakan uji beda T-test untuk membandingkan sikap terhadap dokter kandungan pria dan wanita, serta analisis regresi untuk melihat kontribusi belief of competence pada sikap partisipan. Hasil penelitian menunjukkan bahwa sikap ibu hamil terhadap dokter wanita secara significant lebih positif dibandingkan dokter pria $(\mathrm{t}(262)=3.87, \mathrm{p}<0.001)$. Faktor gender, budaya, dan agama dinilai sebagai kontributor terhadap sikap ini. Sementara ketika ibu hamil memiliki sikap positif terhadap dokter pria, belief of competence dinilai sebagai faktor yang paling berkontribusi $\left(R^{2}=0.46\right.$, $\mathrm{p}<0.001)$.
\end{abstract}

Kata kunci-Sikap, Ibu Hamil, Dokter Kandungan, Studi Komparatif

\begin{abstract}
Indonesia is the fourth most populous country in the world with the majority of the population's religion is Islam. Moslem women have value to limit their physical interaction with men, we assume that there will be some barriers when they met male obstetricians. The purpose of this study is to evaluate differences between pregnant women's attitude towards male obstetricians and female obstetricians. Participants were 132 pregnant women, moslem, wearing hijab in daily basis and first pregnancy. We used comparative method and purposive sampling technique. Pregnant women's attitude measured by scale based on Attitude theory (Ajzen, 2005). Using similar scale, data about belief of competence also collected among the subject. Reliability coefficient for attitude scale was high $(r=0.889$ for male obstetricians and $r=0.931$ for female obstetricians), meanwhile the reliability score for belief of competence scale was very high ( $r=0.95$ for both male and female obstetricians). Data analyzed with quantitative technique, using $T$-test to compare attitudes between male and female obstetricians, also regression coefficient to see the belief of competence's contributions for participant's attitude score. Result showed that pregnant women was significantly had more positive attitude towards female obstetricians than male obstreticians $(t(262)=3.87, p<0.001)$. Gender, culture, and religion were found as contributing factors for this attitude. When pregnant women have positive attitude toward male obstreticians, belief of competence discovered as the most contributing factor $\left(R^{2}=\right.$ $0.46, p<0.001)$.
\end{abstract}

Keywords_Attitude, Pregnant Women, Obstetrician, Comparative Study 


\section{Journal of Psychological Science and Profesion (JPSP)}

Vol.1, No.1, Desember 2017

E-mail: jpsp@unpad.ac.id

\section{PENDAHULUAN}

Kehamilan merupakan hal yang ditunggu-tunggu oleh pasangan menikah yang memutuskan untuk memiliki anak. Menurut BKKBN (Badan Kependudukan dan Keluarga Berencana Nasional, 2013), kehamilan adalah proses yang diawali dengan keluarnya sel telur matang pada saluran telur yang kemudian bertemu dengan sperma, lalu keduanya menyatu membentuk sel yang akan tumbuh. Kehamilan manusia terjadi selama $\quad 40$ minggu antara waktu menstruasi terakhirdan kelahiran (38

minggu dari pembuahan). Waktu kehamilan sendiri dibagi tiga periode, yang biasa disebut trimester.

Masa kehamilan ini merupakan masa yang cukup rentan dan sensitif, baik secara fisik maupun psikis. Dampak yang dirasakan dari kehamilan sendiri juga dapat berbeda antar satu individu dengan individu lainnya. Begitupun penanganan serta hal yang harus dihindari oleh setiap ibu hamil dapat berbeda pula. Hal ini yang mendorong para ibu hamil untuk rutin memeriksakan kondisi kandungan ke dokter spesialis kandungan. Pemeriksaan kehamilan ini sebaiknya dilakukan minimal sebanyak 4 kali, yaitu 1 kali pada trimester pertama, 1 kali pada trimester kedua, dan 2 kali pada trimester ketiga. Pemeriksaan ini penting dilakukan untuk mencegah komplikasi serta mempertahankan kesehatan ibu dan janin selama kehamilan, serta biasanya dilakukan oleh tenaga bidan maupun dokter kandungan.

Menurut Depkes (2009), pelayanan kesehatan oleh profesional (dokter spesialis, kebidanan, dokter umum, bidan, pembantu bidan, dan perawat bidan) untuk ibu selama masa kehamilannya disebut sebagai pelayanan antenatal. Pemeriksaan antenatal sendiri meliputi anamnesa, pemeriksaan umum (pemeriksaan fisik), pemeriksaan laboratorium, pemberian obatobatan, serta penyuluhan bagi ibu hamil. Pemeriksaan fisik sendiri meliputi pemeriksaan berat badan, tinggi badan, tekanan darah, nadi, suhu badan, pembesaran rahim, perut, panggul, letak janin, serta detak jantung janin. Beberapa pemeriksaan ini mungkin sudah sering dialami oleh ibu hamil, namun pemeriksaan lain khususnya yang melibatkan bagian tubuh yang sensitif dapat dinilai sebagai sesuatu yang tidak nyaman bagi ibu hamil. Pemeriksaan rahim misalnya, melibatkan proses dimana dokter kandungan harus melihat dan menyentuh organ intim ibu hamil.

Untuk dapat menjalani pemeriksaan dengan baik, diperlukan kerjasama antara pihak pasien dengan pihak profesional, dimana dalam kasus ini adalah dokter kandungan. Sikap pasien terhadap dokter kandungan menjadi peranan penting untuk kesejahteraan pasien. Sikap merupakan sebuah disposisi untuk memberikan respon favorable atau unfavorable terhadap suatu objek, individu, institusi, atau kejadian. Pada penelitian ini, ingin diketahui bagaimana disposisi dari respon ibu hamil terhadap dokter kandungan pria dan dokter kandungan wanita. Untuk mengetahui sikap terhadap sesuatu, maka digunakan tiga kategori utama yaitu kognitif, afektif, dan konatif (Allport, 1954; McGuire, 1969, dan Hilgard, 1980, dalam Azjen, 2005). Kategori kognitif merupakan kategori yang merefleksikan persepsi ataupun pemikiran terhadap objek. Kategori kognitif menggambarkan belief yang terkait dengan karakteristik atau atribut tertentu dari objek. Kategori kedua, afektif, merupakan evaluasi ataupun perasaan terhadap objek. Respon afektif yang positif dapat berupa kekaguman ataupun apresiasi. Sebaliknya, respon afektif yang negatif dapat berupa perasaan jijik, meremehkan, dan lainnya. Kategori konatif berupa perilaku, intensi, komitmen, maupun aksi lain terhadap objek. Kategori ini menggambarkan mengenai apa yang akan dilakukan oleh individu terkait objek. Kategori konatif yang positif terhadap dokter kandungan misalnya, dapat berupa individu yang datang berobat ke dokter tersebut (Ajzen, 2005). Dalam hal ini, terdapat banyak hal yang dapat mempengaruhi bagaimana pasien merespon terhadap dokter yang menanganinya, salah satunya adalah gender dari dokter tersebut.

Indonesia merupakan negara dengan jumlah penduduk terbesar ke-4 sedunia, dengan jumlah 254,9 juta jiwa. Diketahui bahwa sebanyak 128,1 juta jiwa penduduk tersebut adalah pria, dan 126,8 juta jiwa adalah wanita. Berdasarkan jumlah penduduk diatas, didapatkan bahwa $85 \%$ dari penduduknya beragama Islam (Badan Pusat Statistik, 2015). Saidun (2012) mendeskripsikan penting bagai seorang tenaga professional untuk melihat subjek pasien medis secara keseluruhan dari berbagai perspektif, khususnya Islam. Wanita muslim menganut nilai-nilai yang membatasi 


\section{Journal of Psychological Science and Profesion (JPSP)}

Vol.1, No.1, Desember 2017

E-mail: jpsp@unpad.ac.id

interaksi fisik antara dirinya dengan lawan jenis yang bukan suaminya. Nilai-nilai ini tentunya dipegang sejak kecil dan akan berpengaruh terhadap sikap mereka kepada orang di sekitar mereka dalam kesehariannya. Padela dan Pozo (2010) menyoroti bagaimana ditemukan berbagai kesenjangan antara kode etik medis dan nilai-nilai agama pada beberapa kasus. Mereka mengatakan bahwa penting bagi tenaga medis professional untuk mempertimbangkan aspek latar belakang, agama, dan religiositas di lapangan. Terdapat beberapa hal yang seharusnya dapat diakomodasi dalam pelayanan kesehatan sehingga pasien muslim dapat menjalani proses pelayanan dengan nyaman. Saidun. Ketika Ibu hamil yang muslim bertemu dengan dokter kandungan pria, terdapat kemungkinan akan muncul ketidaknyamanan pada diri mereka, mengingat akan dilakukan pemeriksaan yang sensitif terhadap Ibu hamil tersebut. Ketidaknyamanan ini akan mempengaruhi sikap lbu hamil terhadap dokter kandungan selama proses pemeriksaan. Hal ini ditakutkan berpengaruh pula terhadap proses pemeriksaan kandungan dan berakibat buruk terhadap kesejahteraan pasien. Oleh karena itu, peneliti tertarik untuk mengetahui apakah ada perbedaan antara sikap ibu hamil terhadap dokter kandungan pria dan sikap ibu hamil terhadap dokter kandungan wanita.

Dalam penelitian ini, peneliti ingin menjawab beberapa pertanyaan penelitian yaitu: (1) Apakah terdapat perbedaan antara sikap ibu hamil terhadap dokter kandungan pria dengan sikap ibu hamil terhadap dokter kandungan wanita?; (2) Bagaimana hubungan antara sikap ibu hamil dengan belief of competence ibu hamil terhadap dokter kandungan?

\section{METODE}

Rancangan penelitian yang digunakan dalam penelitian ini merupakan rancangan penelitian non-eksperimental dengan metode komparatif, yaitu metode yang berfokus dalam menemukan persamaan-persamaan dan perbedaanperbedaan tentang benda-benda, tentang orang, prosedur kerja, ide-ide, kritik terhadap orang, kelompok, terhadap suatu ide atau prosedur kerja. Dapat juga membandingkan kesamaan pandangan dan perubahan-perubahan pandangan orang, grup atau negara, terhadap kasus, terhadap orang, peristiwa atau terhadap ide-ide (Christensen, 2007).
Pengambilan sampel dalam penelitian ini menggunakan teknik non probability sampling dengan bentuk purposive sampling. Partisipan yang terjaring adalah 132 orang ibu hamil di Indonesia yang sedang dalam masa kehamilan pertama, beragama Islam, dan mengenakan hijab.

Alat ukur yang digunakan dalam penelitian ini adalah kuisioner mengenai Belief of Competence dan Sikap terhadap Dokter Kandungan Pria dan Wanita yang dibuat oleh peneliti berdasarkan teori Sikap (Ajzen, 2005). Alat ukur Sikap terdiri atas 21 item (7 item untuk tiap aspek sikap), dengan 4 pilihan jawaban (sangat tidak sesuai, tidak sesuai, sesuai, sangat sesuai). Alat ukur belief of competence terdiri atas 15 item, dan partisipan diminta untuk memberi rating dari 1 (paling rendah) hingga 4 (paling tinggi) pada dokter pria dan wanita di tiap kompetensi. Kedua alat ukur ini sudah teruji valid dan memiliki nilai reliabilitas (Cronbach's Alpha) seperti yang tertera di bawah ini:

Tabel 1. Nilai Reliabilitas Alat Ukur

\begin{tabular}{lcc}
\hline \multicolumn{1}{c}{ Alat Ukur } & Reliabilitas \\
\hline $\begin{array}{l}\text { Sikap terhadap } \\
\text { Kandungan Laki-laki }\end{array}$ & Dokter & 0.889 (Tinggi) \\
$\begin{array}{l}\text { Sikap terhadap Dokter } \\
\text { Kandungan Perempuan }\end{array}$ & 0.831 (Tinggi) \\
$\begin{array}{l}\text { Belief terhadap Kompetensi } \\
\text { Dokter Kandungan Laki-laki }\end{array}$ & $\begin{array}{c}\text { 0.950(Sangat } \\
\text { Tinggi) }\end{array}$ \\
$\begin{array}{l}\text { Belief terhadap Kompetensi } \\
\text { Dokter Kandungan Perempuan }\end{array}$ & $\begin{array}{c}0.952 \text { (Sangat } \\
\text { Tinggi) }\end{array}$ \\
\hline
\end{tabular}

Proses pengambilan data dari penelitian ini dilakukan dengan menyebarkan kuesioner secara online dari bulan Oktober sampai dengan November 2016. Proses analisis data dilakukan melalui uji beda $t$-test (untuk melihat perbedaan sikap dan belief terhadap dokter kandungan pria dan wanita) dan analisis regresi (untuk melihat kontribusi belief of competence terhadap dokter kandungan pria dan wanita) dengan menggunakan program SPSS versi 20.0. 


\section{Journal of Psychological Science and Profesion (JPSP)}

Vol.1, No.1, Desember 2017

E-mail: jpsp@unpad.ac.id

\section{HASIL DAN PEMBAHASAN}

Data demografis menjukkan bahwa rentang usia partisipan adalah 20-38 tahun (usia dewasa awal), dengan tingkat pendidikan yang beragam dari SMA (3.8\%), D3 (9.8\%), D4 (3\%), S1 $(68.2 \%)$, hingga S2 (15.2\%). Seluruh partisipan $(100 \%)$ memiliki status sudah menikah. Sebanyak $30.3 \%$ partisipan berada pada kehamilan trimester pertama, $28.8 \%$ partisipan berada pada trimester kedua, dan $40.9 \%$ partisipan berada pada trimester ketiga.

Berdasarkan hasil uji beda yang dilakukan, peneliti menemukan bahwa terdapat perbedaan yang signifikan antara sikap ibu hamil terhadap dokter kandungan pria dengan sikap ibu hamil terhadap dokter kandungan wanita $(\mathrm{t}(262)=3.87$, $p<0.001)$. Rata-rata skor nilai sikap (Mean) partisipan terhadap dokter pria sebesar 57.53, sementara terhadap dokter wanita sebesar 61.00.

Tabel 2. Group Statistics

\begin{tabular}{lrrr}
\hline Kelompok & $\mathbf{N}$ & Mean & SD \\
\hline Dokter pria & 132 & 57.53 & 7.394 \\
$\begin{array}{l}\text { Dokter } \\
\text { wanita }\end{array}$ & 132 & 61.00 & 7.151 \\
\hline
\end{tabular}

Tabel 3. Hasil Uji T

\begin{tabular}{cccc}
\hline Variabel & $\mathbf{T}$ & df & Sig. (two-tailed) \\
\hline Sikap & 3.875 & 262 & 0.000 \\
\hline
\end{tabular}

Jika ditelusuri berdasarkan dimensi-dimensi dari sikap sendiri, dapat dilihat bahwa perbedaan yang signifikan ditemukan pada setiap dimensinya. Dimensi afektif $(\mathrm{t}(262)=15.15, p<$ $0.001)$ dan konatif $(\mathrm{t}(262)=11.69, p<0.001)$ terlihat memiliki taraf signifikansi yang lebih tinggi dibandingkan dimensi kognitif $(\mathrm{t}(262)=2.02, p<$ 0.05). Hal ini membuktikan bahwa perbedaan sikap antara sikap ibu hamil terhadap dokter pria dan dokter wanita terlihat lebih jelas terutama pada dimensi afektif dan konatif.
Tabel 4. Mean dan SD Aspek Sikap

\begin{tabular}{clcc}
\hline Aspek & Dokter & Mean & SD \\
\hline Kognitif & Pria & 21.52 & 3.307 \\
& Wanita & 22.32 & 3.161 \\
Afektif & Pria & 14.01 & 3.785 \\
& Wanita & 21.09 & 3.811 \\
& & & \\
Konatif & Pria & 17.33 & 4.810 \\
& & & \\
& Wanita & 23.21 & 3.208 \\
\hline
\end{tabular}

Hasil analisis regresi yang dilakukan menggambarkan bahwa belief of competence dari ibu hamil dinilai secara signifikan berkontribusi pada sikapnya terhadap dokter pria dan dokter wanita. Belief of competence ibu hamil terhadap dokter pria berkontribusi sebesar $46 \%$ terhadap sikap ibu hamil tersebut $\left(R^{2}=0.46, p<0.001\right)$. Sementara, belief of competence ibu hamil terhadap dokter wanita, berkontribusi sebesar $37.1 \%$ terhadap sikapnya $\left(R^{2}=0.37, p<0.001\right)$.

Hasil yang didapatkan dari penelitian menunjukkan bahwa ibu hamil lebih memiliki sikap yang positif terhadap dokter kandungan wanita daripada dokter kandungan pria. Sikap positif yang dimiliki para ibu hamil lebih didasarkan pada aspek afektif dan konatif. Seorang ibu hamil akan mengeluarkan sikap yang lebih positif pada aspek perasaan dan perilaku ketika bertemu dengan dokter wanita dibandingkan ketika bertemu dengan dokter pria. $\mathrm{Hal}$ ini sejalan dengan penelitian yang dilakukan oleh Januahari (2008) dimana ibu hamil merasa lebih nyaman ketika diperiksa oleh dokter kandungan wanita karena merasa lebih dimengerti akibat struktur tubuh yang sama dan memungkinkan mengalami kehamilan juga.

Haar, Halitsky, dan Stricker (1975) mengatakan bahwa semakin negatif sikap pasien terhadap proses kehamilan dan melahirkan, maka akan semakin tinggi kemungkinan mereka akan memilih dokter wanita. Temuan ini dinilai sesuai dengan penelitian ini, dikarenakan kriteria inklusif dari penelitian ini bahwa partisipan adalah ibu 


\section{Journal of Psychological Science and Profesion (JPSP)}

Vol.1, No.1, Desember 2017

E-mail: jpsp@unpad.ac.id

hamil yang baru mengalami kehamilan pertama. Peneliti menganggap bahwa pengalaman kehamilan pertama akan memicu berbagai kecemasan atau ketakutan terhadap proses yang akan dihadapi.

Aspek afektif ini yang paling utama berkontribusi terhadap sikap positif yang dimiliki para ibu hamil terhadap dokter kandungan wanita. Sejalan dengan aspek konatif yang juga berkontribusi positif terhadap sikap para ibu hamil. Azjen (2005) mengatakan bahwa apabila individu memiliki sikap yang positif terutama pada aspek konatif, individu akan menunjukkan perilaku yang sesuai dengan sikapnya. Hal ini yang membuat para ibu hamil lebih memilih untuk berkonsultasi dan memeriksakan dirinya pada dokter kandungan wanita dibandingkan pada dokter kandungan pria.

Temuan lain dalam penelitian ini menunjukkan bahwa masih ada ibu hamil yang memeriksakan dan mengonsultasikan kehamilannya pada dokter kandungan pria. Walaupun aspek afektif dan konatif lebih tinggi dimiliki para ibu hamil yang memiliki sikap positif terhadap dokter kandungan wanita, masih terdapat para ibu hamil yang memiliki sikap positif terhadap dokter kandungan pria. Namun, sikap positif ini lebih dipengaruhi oleh belief of competence pada dokter kandungan pria. Hal ini menunjukkan ketika ibu hamil memilikisikap positif terhadap dokter kandungan pria, lebih disebabkan karena ibu hamil memiliki pandangan dan keyakinan bahwa dokter kandungan pria memiliki kompetensi dan pengetahuan yang lebih baik dibandingkan dengan dokter kandungan wanita.

Bian, Leslie, dan Cimpian (2017) menemukan bahwa stereotipe yang berasosiasi dengan kemampuan intelektual yang tinggi cenderung ditemukan pada pria dibandingkan wanita. Penelitian ini juga mengkaji terbentuknya stereotipe ini sudah dimulai sejak usia dini. Partisipan yang merupakan anak-anak perempuan yang berusia 6 tahun dan mulai membentuk stereotipe demikian. Hal ini yang menimbulkan partisipasi pada pekerjaan yang bergengsi akhirnya didominasi oleh pria, karena wanita menjadi cenderung menghindari potensi terjun dalam pekerjaan-pekerjaan bergengsi tersebut. Diduga stereotipe inilah yang mempengaruhi sikap ibu hamil tersebut kepada dokter pria yang dianggap lebih pintar.

Pada penelitian lain yang serupa, faktor demografik menjadi peranan penting dalam menentukan hasil penelitian. Di Tel Aviv, Israel
(Piper, Svharts, \& Lurie, 2008) ditemukan sebagian besar partisipan (60.3\%) mengakui bahwa jenis kelamin bukanlah pertimbangan penting ketika memilih dokter kandungan. Faktor yang menjadi pertimbangan utama adalah sikap professional (45.3\%), sopan-santun (25.8\%), sertifikasi (10.8\%), ketersediaan (10.1\%). Sementara di Amerika Serikat (Johnson, dkk. 2005) menemukan bahwa sebagian besar pasien (66.6\%) tidak mengalami bias gender dalam memilih dokter kandungan. Bahkan sebanyak 80.8\% merasa bahwa jenis kelamin dokter tidak akan mempengaruhi kualitas dari pelayanan. Sedangkan pada negara dengan mayoritas penduduk muslim seperti Iraq (Lafta, 2006), ditemukan bahwa $73 \%$ pasien lebih memilih dokter kandungan wanita. Hal ini membuktikan bahwa peranan nilai-nilai agama berpengaruh terhadap preferensi pemilihan, sebagaimana pula dalam penelitian ini.

\section{SIMPULAN}

Hasil penelitian ini menunjukkan bahwa sikap ibu hamil terhadap dokter wanita lebih positif secara signifikan dibandingkan dokter pria. Saat dokter pria memperoleh sikap positif dari seorang ibu hamil, sebagian besar dari sikap tersebut berlandaskan atas kepercayaan ibu hamil bahwa dokter tersebut kompeten dan memiliki pengetahuan yang mumpuni. Sementara jika dokter wanita memperoleh sikap positif dari seorang ibu hamil, selain dari kepercayaan akan kompetensinya, terdapat faktor lain yang berkontribusi. Faktor lain inilah yang menjadi kontributor tambahan untuk menunjang ibu hamil mengeluarkan sikap yang lebih positif terhadap dokter wanita. Faktor ini dapat berupa gender dokter itu sendiri, belief terhadap budaya, dan nilai-nilai agama yang dianut oleh ibu hamil tersebut.

Penelitian selanjutnya diharapkan dapat mengeksplorasi lebih jauh mengenai faktor-faktor yang mendasari perbedaan sikap pasien terhadap dokter pria dan wanita. Selain itu peneliti juga dapat merancang intervensi yang tepat untuk mengatasi kesenjangan ini, demi pengembangan profesi dokter serta kesejahteraan pasien sendiri.

\section{UCAPAN TERIMA KASIH}

Penulis mengucapkan terima kasih kepada para partisipan yang sudah meluangkan waktunya untuk mengisi kuesioner ini. Semoga penelitian ini 


\section{Journal of Psychological Science and Profesion (JPSP)}

Vol.1, No.1, Desember 2017

E-mail: jpsp@unpad.ac.id

memberikan manfaat yang besar untuk peningkatan pelayanan ibu hamil di Indonesia.

\section{DAFTAR PUSTAKA}

Ajzen, Icek. (2005) . Attitudes, Personality, and Behavior. Second Edition. New York: Open University Press

Bian, L., Leslie, S., \& Cimpian, A. (2017). Gender stereotypes about intellectual ability emerge early and influence children's interests. Science,355(6323), 389-391.

Badan Pusat Statistik. (2015). url: https://www.bps.go.id/linkTableDinamis/vie w/id/844/ua897 (diakses pada 7 Maret 2017)

BKKBN. (2013). Penelitian Tentang Peristiwa Kehamilan. url: https://flipbook.bkkbn.go.id/index.php/flipbo ok/flipbook/download/fafsdr6ff1b1330bf755 1e4eede97e2da426.pdf

Christensen, Larry B. (2007). Experimental Methodology Tenth Edition. USA: Pearson Education Inc

DEPKES. (2009). Antenatal Care. url: http://ejournal.litbang.depkes.go.id/index.ph p/hsr/article/viewFile/73191-34988/4274

Haar, E., Halitsky, V., \& Stricker, G. (1975). Factors Related to the Preference for a
Female Gynecologist. Medical Care,13(9), 782-790.

Johnson, A. M., Schnatz, P. F., Kelsey, A. M., \& Ohannessian, C. M. (2005). Do Women Prefer Care From Female or Male Obstetrician-Gynecologists? A Study of Patient Gender Preference. The Journal of the American Osteopathic Association, 105, 369-379.

Lafta, R. K. (2006). Practitioner Gender Preference Among Gynecologic Patients in Iraq. Health Care for Women International,27(2), 125-130.

Padela, A. I., \& Pozo, P. R. (2010). Muslim patients and cross-gender interactions in medicine: an Islamic bioethical perspective. Journal of Medical Ethics,37(1), 40-44.

Piper, I., Shvarts, S., \& Lurie, S. (2008). Women's preferences for their gynecologist or obstetrician. Patient Education and Counseling, 72(1), 109-114.

Saidun, S. (2012). Photographing human subjects in biomedical disciplines: an Islamic perspective. Journal of Medical Ethics, $39(2)$,

Sugiyono. (2006). Statistik Untuk Penelitian. Bandung: CsV. Alfabeta 